\title{
Exacerbated experimental pancreatitis in interleukin-19 knockout mice
}

\author{
Fujimoto $Y^{1}$, Tsuneyama $K^{2}$, Kuramoto $N^{3}$, Hayashi $S^{1}$, Yoshida $N^{1}$, Morioka $A^{1}$, Teramoto $M^{1}$, Nakajima $H^{1}$, Takeuchi $T^{1}$ and Azuma YT ${ }^{1 *}$ \\ ${ }^{1}$ Laboratory of Veterinary Pharmacology, Division of Veterinary Science, Osaka Prefecture University Graduate School of Life and Environmental Science, \\ Izumisano, Osaka 598-8531, Japan \\ ${ }^{2}$ Department of Pathology and Laboratory Medicine, Institute of Biomedical Sciences, Tokushima University Graduate School, Tokushima, Tokushima 770-8503, \\ Japan \\ ${ }^{3}$ Laboratory of Molecular Pharmacology, Setsunan University Faculty of Pharmaceutical Sciences, Hirakata, Osaka 573-0101, Japan
}

\begin{abstract}
Pancreatitis results from the inflammation, fibrosis, and general tissue disruption especially in pancreatic acinar cells. We used the experimental mouse model of acute pancreatitis to examine the roles of interleukin (IL)-19 in pancreatic inflammation. Using gene-targeting, we generated IL-19 knockout (KO) mice. To study the tissue damage during pancreatic inflammation we characterized a mouse model of pancreatitis induced by cerulein. Cerulein is the cholecystokinin analogue and, when it is given to the animals, the excess stimulation leads to abnormally high secretion of digestive enzymes, resulting in acute pancreatitis. We showed that cerulein-induced pancreatitis was exacerbated in IL-19 KO mice. This exacerbated pancreatitis is correlated with the increased autophagy and apoptosis. Our results clearly demonstrated that IL-19 is required for the control in autophagy and apoptosis during acute cerulein-induced pancreatitis.
\end{abstract}

\section{Introduction}

IL-19 was originally found by sequence homology to IL-10 [1], and is a member of the IL-10 family, which also includes IL-20, IL-22, IL24, IL-26, IL-28A, IL-28B, and IL-29 [2]. Recent studies have shown that IL-19 was produced by keratinocytes [3,4], epithelial cells [5-8], macrophages $[9,10], B$ cells $[11,12]$, and vascular smooth muscle cells [13]. Our previous studies showed that IL-19-knockout (KO) mice were more susceptible to experimental acute colitis induced by dextran sulfate sodium, TNBS, and oxazolone $[10,14,15]$. These results indicate that IL-19 plays as the anti-inflammatory effector.

The role of inflammatory mediators in host defense and in wound healing has long been appreciated. Excessive uncontrolled inflammation can result in a variety of pathological conditions, including chronic inflammation and autoimmune diseases. Inappropriate activation of innate and adaptive immunity against normal cells and tissues normal constituents results in inflammatory diseases [16]. Pancreatitis is disease characterized by inflammation, fibrosis, and general tissue disruption especially in pancreatic acinar cells, and its progression and pathogenesis are mediated by several inflammatory cytokines and antiinflammatory cytokines that are released form infiltrated monocytes and macrophages [17]. Acute pancreatitis is increasing in the world and $20 \%$ of acute pancreatitis is associated with substantial morbidity and mortality $[18,19]$. The commonest associations of acute pancreatitis are alcohol abuse or gallstone migration. Inappropriate conversion of trypsinogen to trypsin within the pancreatic acinar cells leads to the development of pancreatic inflammation [20]. However, little is known about the exact immunological role of IL-19 in the development and regulation of pancreatitis. Cerulein-induced pancreatitis is a wellcharacterized model of acute pancreatic inflammation. Cerulein is the cholecystokinin (CCK) analogue and, when it is given to the animals, the excess stimulation leads to abnormally high secretion of digestive enzymes, resulting in acute pancreatitis. In this study, we investigated the role of IL-19 in cerulein-induced pancreatitis which is useful for the study of interstitial inflammation and acinar cell necrosis in the pancreas.

\section{Materials and methods}

\section{Mice}

We constructed targeting vectors for the IL-19 gene and used them

Correspondence to: Azuma YT, Laboratory of Veterinary Pharmacology, Division of Veterinary Science, Osaka Prefecture University Graduate School of Life and Environmental Science, 1-58 Rinku-ohraikita, Izumisano, Osaka 5988531, Japan, E-mail: azuma@vet.osakafu-u.ac.jp

Key words: IL-19, anti-inflammatory cytokine, pancreatitis

Special Issue: Academic seeds for drugs

Katsura Takano

Associate Professor

Division of Veterinary Science

Graduate School of Life and Environmental Sciences

Osaka Prefecture University

Japan

Yasu-Taka Azuma, Ph.C., Ph.D.

Associate Professor

Principal Investigator at Laboratory on Veterinary Pharmacology Osaka Prefecture University

Japan

Received: June 26, 2017; Accepted: July 24, 2017; Published: July 27, 2017 
to generate IL-19 KO mice [14]. C57BL/6-IL-19 heterozygous mice were intercrossed to generate mutant and control mice.Age-matched mice (9-12 weeks old) were used in all experiments. All proceduresused in this study complied with institutionalpolicies of the Osaka Prefecture University Animal Care and Use Committee.

\section{Cerulein-induced pancreatitis}

Mice were fasted for $16 \mathrm{~h}$ before the experiment and received eight intra-peritoneal injections of cerulein at $50 \mu \mathrm{g} / \mathrm{kg}$ or $75 \mu \mathrm{g} / \mathrm{kg}$ at hourly intervals over $7 \mathrm{~h} \mathrm{[21].} \mathrm{Control} \mathrm{mice} \mathrm{were} \mathrm{administered} \mathrm{saline.}$

\section{Serum amylase level}

Blood samples collected from tail vein were centrifuged at $10,000 \times \mathrm{g}$ for $10 \mathrm{~min}$ and then stored at $-20^{\circ} \mathrm{C}$. The serum amylase assay was determined using the Amylase Assay (MaxDiscovery ${ }^{\mathrm{TM}}$ ) (Bioo Scientific Corporation, Austin, TX).

\section{Histology and immunohistochemistry}

The pancreas was fixed with $10 \%$ neutral buffered formalin and embedded in paraffin. Sections were routinely stained with hematoxylin and eosin (HE). MPO activity and TUNEL staining were routinely detected according to the manufacturer's instructions [22]. Immunohistochemistry was performed as previously described [22]. Primary antibodies against p62, cleaved caspase-3, and Ki-67 were used.

\section{Statistical analysis}

Results are expressed as the mean \pm standard error of the mean (SEM). Differences in parametric data were evaluated using Student's t tests. Differences with $P$ values of less than 0.05 were considered significant.

\section{Results}

\section{Mild condition of pancreatitis induced by cerulein at low dose}

In the first experiments, mice were injected with cerulein at $50 \mu \mathrm{g} /$ $\mathrm{kg}$. We examined the serum amylase activity in mice with ceruleininduced pancreatitis. Cerulein induced the serum amylase activities in WT and IL-19 KO mice compared to saline-injected mice. Serum amylase level was slightly higher but not significant ( $\mathrm{p}=0.114)$ in IL-19 $\mathrm{KO}$ mice with cerulein-induced pancreatitis than in WT mice (Figure 1A). In addition, mice given cerulein $(50 \mu \mathrm{g} / \mathrm{kg})$ showed no significant differences in body weight change between WT and IL-19 KO mice (Figure 1B).

We next examined histological changes in the respective mice. IL-19 KO mice after saline administration showed no vacuolization, no degeneration, and no omission (loss) in acinar cells compared to WT mice. Mice after cerulein $(50 \mu \mathrm{g} / \mathrm{kg})$ administration showed the detachment, degeneration, and atrophy of acinar cells with interstitial edema and inflammatory cells infiltration (Figure 2). However, there was no notable difference in the severity of histological characterization when the pancreas from WT and IL-19 KO mice were compared. As shown in Figure 3, cerulein $(50 \mu \mathrm{g} / \mathrm{kg})$ injection increased pancreatic MPO activity. However, the level of MPO activity was similar in WT and IL-19 KO mice. In addition, cerulein $(50 \mu \mathrm{g} / \mathrm{kg})$ injection resulted in a small number of apoptosis in acinar cells. However, there was no notable difference in the number of apoptosis evaluated by TUNEL staining (Figure 3 right panels).
(A)

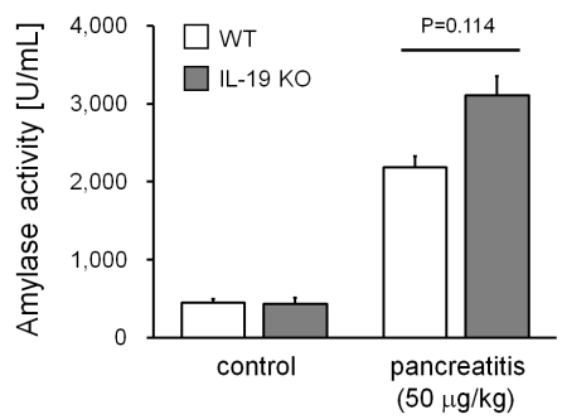

(B)

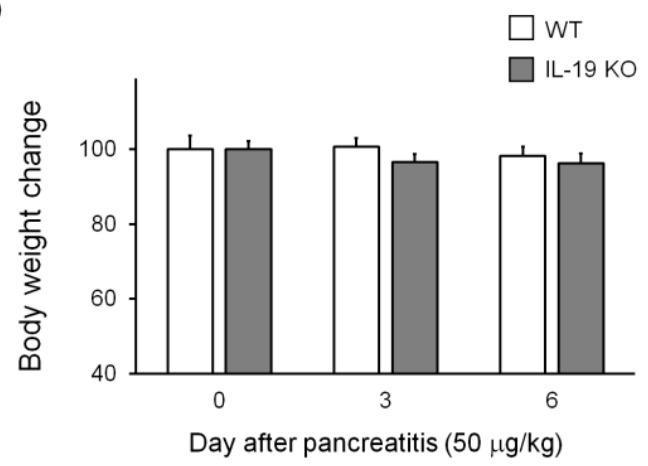

Figure 1. Serum amylase levels in IL-19 KO mice with cerulein-induced pancreatitis Serum amylase was measured for WT $(\mathrm{n}=5)$ and IL-19 KO $(\mathrm{n}=5)$ mice at $12 \mathrm{~h}$ after the last injection of cerulein at $50 \mu \mathrm{g} / \mathrm{kg}$. (B) Body weight in IL-19 KO mice with cerulein-induced pancreatitis. The percent weight losses of WT $(n=4)$ and IL-19 KO $(n=5)$ mice were monitored up to 6 days after cerulein injection. Each left panel shows low magnification and each right panel shows high magnification. $* \mathrm{P}<0.05$ compared with WT.

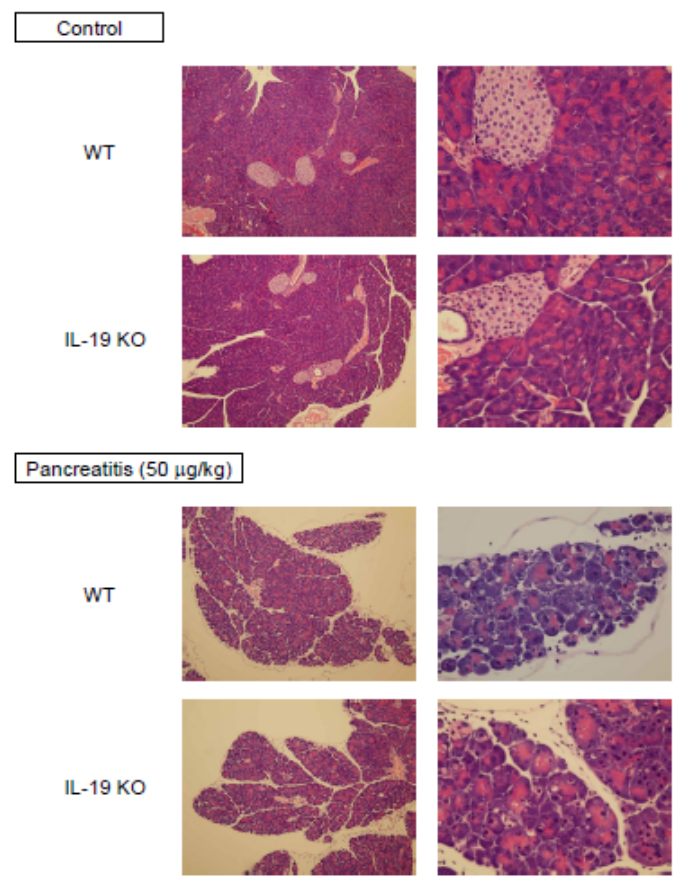

Figure 2. Cerulein-induced pancreatic tissue damage in IL-19 KO mice. HE staining of the pancreas from saline-injected mice ( $\mathrm{n}=3$; upper) and cerulein-injected mice $(\mathrm{n}=5$; lower) at $12 \mathrm{~h}$ after the last injection. Representative sections are shown. 


\section{Severe condition of pancreatitis induced by cerulein at high dose}

Next, mice were injected with cerulein at $75 \mu \mathrm{g} / \mathrm{kg}$. Serum amylase level was significantly higher in IL-19 KO mice with high dose ceruleininduced pancreatitis than in WT mice (Figure 4A). In accordance with the observed significance in amylase activities, IL-19 KO mice given a high dose of cerulein showed a severe weight loss compared to WT mice given the same dose of cerulein (Figure 4B).

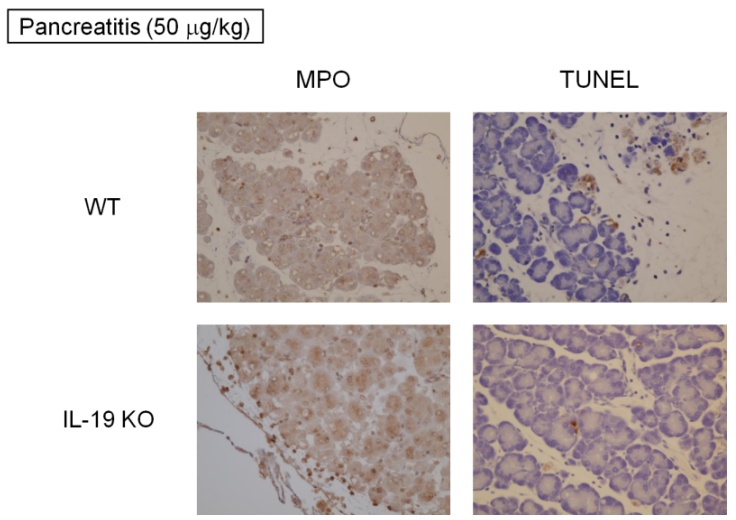

Figure 3. MPO activity and TUNEL staining. MPO activity (left panels) and TUNEL staining (right panels) of the pancreas from WT mice $(n=5)$ and IL-19 KO mice $(n=5)$ with cerulein-induced pancreatitis. Representative sections are shown.

(A)

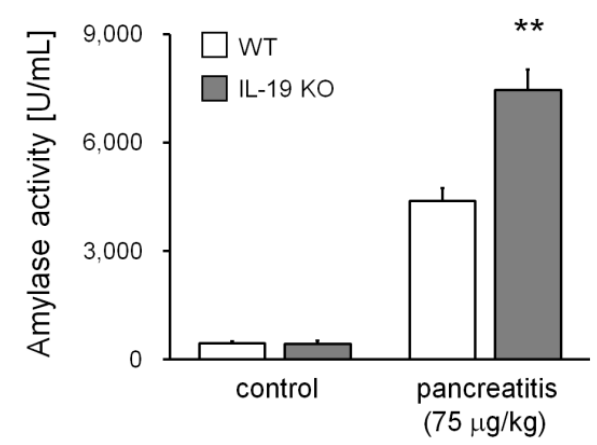

(B)

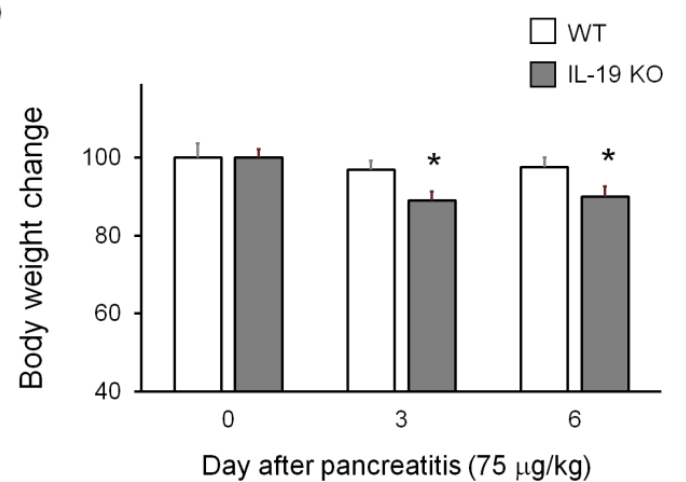

Figure 4. Increased serum amylase levels in IL-19 KO mice with cerulein-induced pancreatitis. Serum amylase was measured for WT $(n=7)$ and IL-19 KO $(n=9)$ mice at $12 \mathrm{~h}$ after the last injection of cerulein at $75 \mu \mathrm{g} / \mathrm{kg}$. $* * \mathrm{P}<0.01$ compared with WT. (B) Decreased body weight in IL-19 KO mice with cerulein-induced pancreatitis. The percent weight losses of WT $(n=11)$ and IL-19 KO $(n=11)$ mice were monitored up to 6 days after cerulein injection. $* \mathrm{P}<0.05$ compared with WT.
Further histological analysis of the pancreas from IL-19 KO mice with cerulein-induced pancreatitis showed severe interstitial edema and severe degeneration in acinar cells (Figure 5 left panels). In contrast, there was no notable difference in infiltrating cells by histological evaluation. Cerulein $(75 \mu \mathrm{g} / \mathrm{kg})$ injection more increased pancreatic MPO activity compared to cerulein $(50 \mu \mathrm{g} / \mathrm{kg}$ ) (Figure 5 right panels and Figure 3). However, the level of MPO activity was similar in WT and IL-19 KO mice.

We performed immunohistochemical detections of p62 (autophagy-associated factor), cleaved caspase-3 (apoptosis-associated factor), and Ki-67 (cellular proliferation-associated protein). As shown in Figure 6, the pancreas of IL-19 KO mice contained a high level of p62
Pancreatitis $(75 \mu \mathrm{g} / \mathrm{kg})$

WT

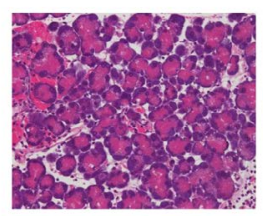

IL-19 KO

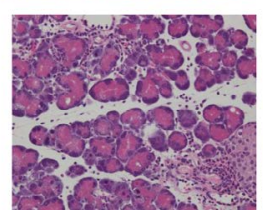

MPO
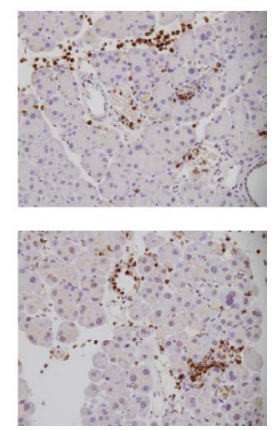

Figure 5. Cerulein-induced pancreatic tissue damage in IL-19 KO mice. HE staining (left panels) and MPO activity (right panels) of the pancreas from WT $(\mathrm{n}=5)$ and IL-19 KO $(\mathrm{n}=5)$ mice at $12 \mathrm{~h}$ after the last injection of cerulein at $75 \mu \mathrm{g} / \mathrm{kg}$. Representative sections are shown.

\section{Pancreatitis $(75 \mu \mathrm{g} / \mathrm{kg})$}

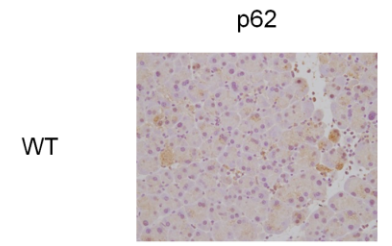

cleaved caspase-3
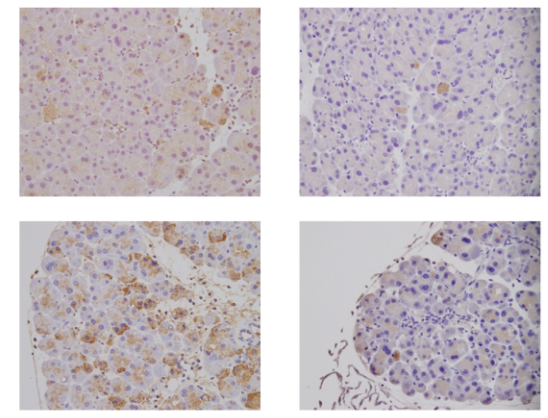

$\mathrm{IL}-19 \mathrm{KO}$

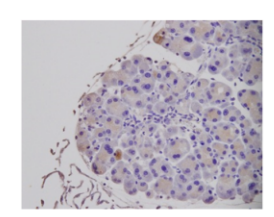

Ki-67

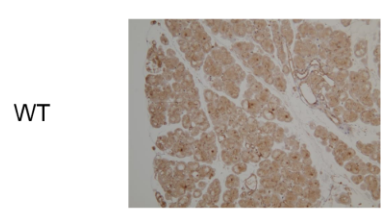

IL-19 KO

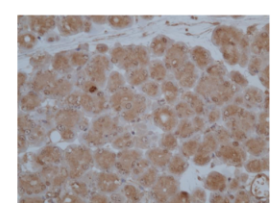

Figure 6. Immunohistochemical staining. Immunohistochemical detections of p62, cleaved caspase 3, and Ki-67 in the pancreas from WT $(n=5)$ and IL-19 KO $(n=5)$ mice with cerulein-induced pancreatitis. Representative sections are shown. 
following cerulein $(75 \mathrm{~g} / \mathrm{kg})$ administration. In addition, the detection of cleaved caspase- 3 was increased in IL-19 KO mice with ceruleininduced pancreatitis (Figure 6 upper right panels). Strikingly, the activity of proliferation in the pancreas of IL-19 KO mice with ceruleininduced pancreatitis (evaluated using anti-Ki-67 antibody) was similar to that of WT mice (Figure 6 lower panels).

\section{Discussion}

In this study, our experiments highlighted several novel aspects of the anti-inflammatory effects of IL-19 in cerulein-induced pancreatitis in vivo. We show that cerulein-induced pancreatitis was exacerbated in IL-19 KO mice. The severe phenotype following genetic ablation of IL-19 was evident only when it was administered at $75 \mu \mathrm{g} / \mathrm{kg}$, as mice given cerulein at $50 \mu \mathrm{g} / \mathrm{kg}$ showed no marked change in amylase activity, body weight, or histological damage. The more severe pancreatic inflammation following genetic ablation of IL-19 was accompanied by an increased level of autophagy, which has been implicated in the pathogenesis of pancreatitis. Cerulein is the CCK analogue and, when it is given to the animals, the excess stimulation leads to abnormally high secretion of digestive enzymes, resulting in acute pancreatitis. The pancreas of this model is histologically quite similar to the early phase of acute pancreatitis in humans [23]. The autophagy, as well as stress and inflammation, are constant features in the pathology of human pancreatitis [24]. It is well known that p62 plays a role in a cellular autophagic process [25]. Furthermore, p62 has been found to play an important role in the autophagy of pancreatitis $[26,27]$. The increased level of p62 suggests facilitated autophagy in cerulein-induced pancreatitis. The autophagy has been suggested to be beneficial to minimize tissue damages by preventing inflammation accompanied with necrosis [28]. However, to date, there have been no reports examining the role of IL-19 in cellular autophagy. We press that this is first reported to show the relation of IL-19 with autophagy. These results suggest that the acinar cell damage in the pancreas of IL-19 KO mice results in enhanced autophagy.

Apoptosis, a programmed cell death, is thought to be a final protective mechanism to minimize tissue damages by preventing the release of digestive enzymes and proteases into the extracellular spaces [29]. Our analysis of IL-19 KO mice showed that there was an increase in the expression of cleaved caspase-3, an apoptosis marker. In the previous study, treatment of monocytes with mouse IL-19 induced mouse monocyte apoptosis by the production of IL- 6 , TNF- $\alpha$, and reactive oxygen species [30]. This previous report did not support our data. These results suggest that IL-19 plays differential roles in different types of cell. Inflammatory responses also are related to onset and development of animals with pancreatitis [31,32]. We examined whether the deficiency of IL-19 affects neutrophils infiltration. Strikingly, the infiltration of neutrophils in the pancreas of IL-19 KO mice (evaluated by MPO activity) was similar to that of WT mice. These results further show that increased infiltration of neutrophils may not be absolutely required for the acinar cell damage of IL-19 KO mice. Therefore, our results suggest that IL-19 may protect pancreatic inflammation through the regulation of autophagy and apoptosis in an acinar cell. It is possible that IL-19 may not regulate the infiltration of inflammatory cells in the pancreas.

Our strength of this study is that there is an interaction of IL-19 with pancreatitis. Up to the present, little has been reported on possible relation of IL-19 in pancreatic diseases including pancreatitis. Our results indicate that although IL-19 may play an important role in controlling pancreatic inflammation as a new function, it may constitute one of several potential cellular and immunological mechanisms that can contribute to pancreatic pathology.

\section{References}

1. Gallagher G, Dickensheets H, Eskdale J, Izotova LS, Mirochnitchenko OV(2000) Cloning, expression and initial characterization of interleukin-19 (IL-19), a novel homologue of human interleukin-10 (IL-10). Genes Immun 1: 442-450. [Crossref]

2. Sabat R, Wallace E, Endesfelder S, Wolk K (2007) IL-19 and IL-20: two novel cytokines with importance in inflammatory diseases. Expert OpinTher Targets 11: 601612. [Crossref]

3. Kunz S, Wolk K, Witte E, Witte K, Doecke WD, et al. (2006) Interleukin (IL)-19, IL-20 and IL-24 are produced by and act on keratinocytes and are distinct from classical ILs. Exp Dermatol 15: 991-1004. [Crossref]

4. Yano S, Banno T, Walsh R, Blumenberg M (2008) Transcriptional responses of human epidermal keratinocytes to cytokine interleukin-1. J Cell Physiol 214: 1-13. [Crossref]

5. Bettaccini AA, Baj A, Accolla RS, Basolo F, Toniolo AQ (2005) Proliferative activity of extracellular HIV-1 Tat protein in human epithelial cells: expression profile of pathogenetically relevant genes. BMC Microbiol 5:20. [Crossref]

6. Zhong H, Wu Y, Belardinelli L, Zeng D (2006) A2B adenosine receptors induce IL-19 from bronchial epithelial cells, resulting in TNF- $\alpha$ increase. Am J Respir Cell Mol Biol 35: 587-592. [Crossref]

7. Huang F, Kao CY, Wachi S, Thai P,RyuJ, et al. (2007) Requirement for both JAKmediated PI3K signaling and ACT1/TRAF6/TAK1-dependent NF- $\kappa B$ activation by IL-17A in enhancing cytokine expression in human airway epithelial cells. $J$ Immunol 179: 6504-6513. [Crossref]

8. Huang F, Wachi S, Thai P, ArtemLoukoianovBS, Kin HupTanBS, et al. (2008) Potentiation of IL-19 expression in airway epithelia by IL-17A and IL-4/IL-13: important implications in asthma. J Allergy Clin Immunol 121: 1415-1421. [Crossref]

9. Wolk K, Witte K, Witte E, Proesch S, Schulze-Tanzil G,et al. (2008) Maturing dendritic cells are an important source of IL-29 and IL-20 that may cooperatively increase the innate immunity of keratinocytes. J Leukoc Biol 83: 1181-1193. [Crossref]

10. Azuma YT, Matsuo Y, Kuwamura M, YancopoulosGD, Valenzuela DM,et al. (2010) Interleukin-19 protects mice from innate-mediated colonic inflammation. Inflamm Bowel Dis 16: 1017-1028. [Crossref]

11. Wolk K, Kunz S, Asadullah K, Sabat R (2002) Immune cells as sources and targets of the IL-10 family members? J Immunol168: 5397-5402. [Crossref]

12. Fickenscher H, Hör S, Küpers H, KnappeA, WittmannS, et al. (2002) The interleukin-10 family of cytokines. Trends Immunol23: 89-96. [Crossref]

13. Tian Y, Sommerville LJ, Cuneo A, Kelemen SE, Autieri MV (2008) Expression and suppressive effects of interleukin-19 on vascular smooth muscle cell pathophysiology and development of intimal hyperplasia. Am J Pathol173: 901-909. [Crossref]

14. Matsuo Y, Azuma YT, Kuwamura M, Kuramoto N, Nishiyama K, et al. (2015) Interleukin 19 reduces inflammation in chemically induced experimental colitis. Int Immunopharmacol 29:468-475. [Crossref]

15. Fujimoto Y, Azuma YT, Matsuo Y, Kuwamura M, Kuramoto N, et al. (2017) Interleukin-19 contributes as a protective factor in experimental Th2-mediated colitis. Naunyn Schmiedebergs Arch Pharmacol 390: 261-268. [Crossref]

16. Azuma YT, Nakajima H, Takeuchi T (2011) IL-19 as a potential therapeutic in autoimmune and inflammatory diseases. Curr Pharm Des 17: 3776-3780. [Crossref]

17. Pandol SJ, Saluja AK, Imrie CW, Banks PA (2007) Acute pancreatitis: bench to the bedside. Gastroenterology 133: 1056.e1-1056.e25. [Crossref]

18. Lund H, Tonnesen H, Tonnesen MH, Olsen O (2006) Long-term recurrence and death rates after acute pancreatitis. Scand J Gastroenterol 41: 234-238. [Crossref]

19. Williams M, Simms HH (1999) Prognotic usefulness of scoring systems in critically ill patients with severe acute pancreatitis. Crit Care Med 27: 901-907. [Crossref]

20. Nakada S, Tsuneyama K, Kato I, Tabuchi Y, Takasaki I, et al. (2010) Identification of candidate genes involved in endogenous protection mechanisms against acute pancreatitis in mice. Biochem Biophys Res Commun 391: 1342-1347. [Crossref]

21. Saeki K, Kanai T, Nakano M, Nakamura Y, Miyata N, et al. (2012) CCL2-induced migration and SOCS3-mediated activation of macrophages are involved in ceruleininduced pancreatitis in mice. Gastroenterology 142: 1010-1020. [Crossref]

22. Kumada T, Tsuneyama K, Hatta H, Ishizawa S, Takano Y (2004) Improved 1-h rapid immunostaining method using intermittent microwave irradiation: practicability based on 5 years application in Toyama Medical and Pharmaceutical University Hospital. Mod Pathol 17: 1141-1149. [Crossref] 
23. Cheung YC, Leung PS (2007) Acute pancreatitis: animal models and recent advances in basic research. Pancreas 34: 1-14. [Crossref]

24. Hall JC, Crawford HC (2014) The conspiracy of autophagy, stress and inflammation in acute pancreatitis. Curr Opin Gastroenterol 30: 495-499. [Crossref]

25. Komatsu M, Waguri S, Koike M, Sou YS, Ueno T, et al. (2007) Homeostatic levels of p62 control cytoplasmic inclusion body formation in autophagy-deficient mice. Cell 131: 1149-1163. [Crossref]

26. Grasso D, Ropolo A, Lo Ré A, Boggio V, Molejón MI, et al. (2011) Zymophagy, a nove selective autophagy pathway mediated by VMP1-USP9x-p62, prevents pancreatic cell death. J Biol Chem 286: 8308-8324. [Crossref]

27. Rivera JF, Gurlo T, Daval M, Huang CJ, Matveyenko AV, et al. (2011) Human-IAPP disrupts the autophagy/lysosomal pathway in pancreatic $\beta$-cells: protective role of p62positive cytoplasmic inclusions. Cell Death Differ 18: 415-426. [Crossref]
28. Ropolo A, Grasso D, Pardo R, Sacchetti ML, Archange C, et al. (2007) The pancreatitisinduced vacuole membrane protein 1 triggers autophagy in mammalian cells. $J$ Biol Chem 282: 37124-37133. [Crossref]

29. Kaiser AM, Saluja AK, Sengupta A, Saluja M, Steer ML (1995) Relationship between severity, necrosis, and apoptosis in five models of experimental acute pancreatitis. Am J Physiol 265: C1295-C1304. [Crossref]

30. Liao YC, Liang WG, Chen FW, Hsu JH, Yang JJ, et al. (2002) IL-19 induces production of IL-6 and TNF-alpha and results in cell apoptosis through TNF-alpha. J Immunol 169 : 4288-4297. [Crossref]

31. Zhuang X, Shen J, Jia Z, Wu A, Xu T, et al. (2016) Anti-B7-H3 monoclonal antibody ameliorates the damage of acute experimental pancreatitis by attenuating the inflammatory response. Int Immunopharmacol 35: 1-6. [Crossref]

32. Cen Y, Liu C, Li X, Yan Z, Kuang M, et al. (2016) Artesunate ameliorates severe acute pancreatitis (SAP) in rats by inhibiting expression of pro-inflammatory cytokines and Toll-like receptor 4. Int Immunopharmacol 38: 252-260. [Crossref]

Copyright: (C2017 Fujimoto Y. This is an open-access article distributed under the terms of the Creative Commons Attribution License, which permits unrestricted use, distribution, and reproduction in any medium, provided the original author and source are credited. 